\title{
IDEAL COMBINATIONS OF GOVERNMENT SYSTEM AND PARTY SYSTEM FOR STABILITY AND EFFECTIVENESS OF THE GOVERNMENT
}

\author{
Widayati \\ UNISSULA Semarang, Central Java \\ widayati@unissula.ac.id \\ Winanto \\ UNISSULA Semarang, Central Java \\ winanto@unissula.ac.id
}

\begin{abstract}
Abstrack
Indonesia since before independence until the time the core adopted a multiparty system. While the system of government changes, from a presidential, parliamentary, quasi presidential system. Multiparty presidential government systems can disrupt the stability and effectiveness of the government because there must be a coalition of political parties in the government, the preparation of the cabinet by the President must consider and accommodate the interests of coalition political parties, decision making or policy-making must also consider the interests of coalition political parties, so it will require longer time. The coalition of political parties is very fluid and pragmatic, so there may be a change in the coalition because there is a possibility that political parties that were outside the coalition will then enter the government coalition, and vice versa. Exit the entry of political parties in the government coalition will certainly be very disturbing, because political parties who have just joined the government will demand a seat in the government, especially in the cabinet. Unloading pairs of the cabinet or dismantling pairs of government seats will often occur. This of course greatly disrupts the stability and effectiveness of government. Therefore, a presidential government system ideally does not combine with a multi-party system. A change from a multi-party system to a simple multi-party system is needed, or if possible with a two-party system.
\end{abstract}

Keyword : Effectiveness of Government, Stability, System, The Presidential.

\section{A. INTRODUCTION}

The government system is a national Identity. ${ }^{1}$ Institutions that have the right to adjust the Constitution as the highest law with the demands of the times is the

1 Sofian Effendi, The government system is a national Identity, Journal Ketahanan Nasional, Volume 10 Number 2, 2005 page 1. country's highest institution, the MPR. ${ }^{2}$ One of the demands for reform is the amendment to the 1945 Constitution. To carry out the demands for reform, the People's Consultative Assembly (MPR in Indonesian) as a state

2 Ahmad Yani, Indonesian Government System: Theory Approach and Constitutional Practice of 1945 Law, Journal Legislasi Indonesia, Volume 15, Nomor 2, Juli 2018, page 55. 
institution has the authority to amend and enact the Constitution, has worked democratically, and institutionally amended the Law. Basic Law.

Theoretically, the system government experienced progression from classical to modern. ${ }^{3}$

Amendments to the 1945 Constitution were carried out in stages because they prioritized articles agreed by all the factions in the MPR, then continued with changes to articles that were more difficult to obtain agreement. In amending the 1945 Constitution, the MPR made a political agreement, one of which was to reinforce the presidential government system. The basic agreement to reinforce the presidential government system aims to strengthen a stable, effective, and democratic government system adopted by the Republic of Indonesia, which in 1945 was chosen by the founder of the Indonesian state. the presidential government system is more suitable to be applied in Indonesia. Because, when Indonesia had implemented a parliamentary government system, the practice of running a state life was never stable. ${ }^{4}$

The presidential government system is not explicitly stated in the 1945 Constitution of the Republic of Indonesia. However, the

3 Muliadi Anangkota, Theoretically the system government experienced progression from classical to modern, Journal Cosmogov, Volume 3, Number 2, page 147.

4 Comprehensive Paper on Amendments to the 1945 Constitution of the Republic of Indonesia, Background, Process, and Results of Discussion 1999-2002, Book I, Secretariat General and Registrar of the Constitutional Court, Jakarta, 2010, page. 160 characteristics of a presidential government system can be found in Article 4 paragraph (1) which states that "The President of the Republic of Indonesia holds the power of the government under the Law Basic Law ", which shows that the President is the head of government, and Articles 10 through 15 that regulate the rights of the president which shows that the President is the head of state. The position of the President as head of government and at the same time as head of state is one of several features of the presidential government system.

In the context of Indonesia, the Constitution which holds up is the 1945 Constitution, if examined, the 1945 Constitution regulates people's sovereignty twice, firstly on the opening of the fourth paragraph, "then arranged the national independence of Indonesia that in a constitution of the sovereign state of Indonesia Democracy and Government System People ... "Secondly, in article 1ayat (2) of the 1945 Constitution, the results of the amendment read, Sovereignty is in the hands of the people and implemented according to the law Basic". Thus, the 1945 Constitution is firmly fundamental in government democracy because it is based on people's sovereignty. ${ }^{5}$

The application of a constitutional system will be related to another constitutional system. For effective implementation and stable governance, it is necessary to have

5 Cora Elly Noviati, Democracy and Government System, Journal of Constitution Volume 10 Number 2, June 2013. Page 335. 
accuracy in combining various constitutional systems so that they can be implemented properly. In Indonesia, the combination chosen is a presidential government system and the party system is multi-party. This is often the subject of discussion because it is considered an improper combination because it is considered to be able to disrupt the stability and effectiveness of government. For this reason, it is necessary to find the right and good solution so that the government runs stable and effective.

\section{B. RESEARCH METHODE}

Legal research is a research process to find the rule of law, legal principles, and legal doctrines to address the legal issues at hand.. ${ }^{6}$ This study uses a normative legal approach, which is research that places the law as a norm system building. Normative legal research examines the rules or rules of law as a building system associated with a legal event. ${ }^{7}$ This study uses secondary data consisting of Primary Legal Materials, Secondary Legal Materials, and Tertiary Legal Materials which are sourced from legislation, books, literature, papers, and other data sources. Data is used through library studies, data collection is done by way of conventional search, collection, and study of documents such as reading, viewing, listening, and with information technology (internet media). Data that has been collected and processed will be

6 Peter Mahmud Marzuki, Law Research, Prenada Media, Jakarta, 2005, page. 35

7 Mukti Fajar dan Yulianto Achmad, The dualism of Normative \& Empirical Law Research, Prints I, Pustaka Pelajar, Yogyakarta, 2010, page. 36 analyzed by normative methods which will then be presented descriptively.

\section{DISCUSSION}

\section{Government Systems}

Government systems are known in the world, namely presidential government systems, and parliamentary government systems. In addition to the two systems, there are also countries that have their own variations of government systems according to the conditions and needs of the country concerned. A country can implement a mixed government system, which is not a presidential government system and not a parliamentary government system, but its government system is quasipresidential or quasi-parliamentary government.

Jimly Asshiddiqie's opinion about the system of government in the world, there are four models, namely the United Kingdom, the United States, France, and Switzerland. The United States has a presidential system. Almost all countries on the American continent, except for a few countries such as Canada, imitate the United States in terms of this system of government. On the European continent and most Asian countries in general use the British model, namely the parliamentary system. But France has its own model that is mixed or commonly referred to as a "hybrid system". In general, the countries of the former French colony in Africa adopted a mixed system. In one aspect there is a distinction between the Head of State and the Head of Government, but the Head of State is the 
President who is elected and is directly responsible to the people as in the presidential system. While the Head of Government, on one hand, is accountable to the President, but on the other hand, he was appointed because of his position as the winner of the election who occupies parliamentary seats, and therefore he is also responsible for the parliament. $^{8}$

The tendency for the adoption of a mixed system arises because of the awareness that in a presidential or parliamentary government system, weaknesses are always found in addition to the inherent strengths of each. ${ }^{9}$

In a presidential government system, the executive body does not depend on the legislature, and the executive has a certain term of office. The freedom of the executive body to the legislature results in the position of the executive body being stronger in dealing with the legislature. Ministers in a presidential cabinet can be chosen at the discretion of the president, without being influenced by political parties, the president's choice of the candidate can be based on expertise and other factors that are considered important. $^{10}$

8 Jimly Asshiddiqie, Constitutional Law and Pillars of Democracy, Flakes of Legal Thinking, Media, and Human Rights, Secretariat General and Registrar of the Constitutional Court Indonesian Republic, Jakarta, 2006, page 110

9 Ibid. Page, 111

10 Miriam Budiardjo, Fundamentals of Political Science, Gramedia, Jakarta, Prints IX, Maret 1985, page. 212
The executive power belongs to the President, and ministers are responsible to the President, not to the legislature. Therefore, ministers cannot be dismissed by the legislature. ${ }^{11}$ In a presidential government system, the President is usually directly elected by the people and is accountable to the people who voted for him.

Earl of Balfour expressed his opinion about the presidential system that implements presidential and vice-presidential elections in certain terms of office as follows: under the Presidential system, the effective head of the national administration is elected for a fixed term. He is practically irremovable. Even if he is proved to be inefficient, even if becomes unpopulsr, even if his policy is unacceptable to his countrymen, he and his methods must be endured until the moment comes for a new election. ${ }^{12}$

The presidential system that is often referred to is the presidential system in the United States which maintains Montesquieu's teachings, where the three state powers namely executive, legislative, and judiciary are sharply separated from each other and hold checks and balances. The power to make laws is in the hands of Congress, while

11 Moh. Kusnardi dan Harmaily Ibrahim, Indonesian Constitutional Law, Center for Constitutional Law Studies, Faculty of Law of s Indonesian University and Sinar Bakti, Jakarta, Prints V, 1983, page. 176

12 H.M. Laica Marzuki, Take a walk in the Law Domain, Book One, Secretariat General and Registrar of the Constitutional Court Indonesian Republic, Jakarta, 2006, page. 39 
the President has the right to veto the laws that have been made. The executive power belongs to the President, and because the President is elected by the people, he is not accountable to the parliament but is responsible to the voters (the people)..$^{13}$

A President in a presidential government system is the chief executive, and cannot be toppled only because of differences of opinion with Congress. The President cannot be contested as long as his term of office has not expired, except in certain cases. The judiciary is carried out by judicial bodies which by principle cannot be influenced by other powers. The judge is appointed for life as long as his behavior is beyond reproach.

In a parliamentary system of government, the executive and legislative bodies depend on one another. The cabinet as part of the executive body responsible is expected to reflect the political forces in the legislature that supports it, and the death of the cabinet depends on support in the legislature. ${ }^{14}$

Parliamentary government system causes the responsibility of ministers to the parliament/legislative body, so every cabinet that is formed must have the support of trust with the most votes from parliament, which means that government or cabinet policies should not deviate from

13 Moh. Kusnardi dan Harmaily Ibrahim, op.cit. page. 176

14 Miriam Budiardjo, op.cit. page. 210 what is desired by the legislature/parliament. ${ }^{15}$

The balance of relations between the executive and legislative bodies will be easily achieved if there is a political party that is large enough in the majority to form a cabinet on its behalf. If not, an attempt to form a coalition cabinet based on cooperation between several political parties which together reach a majority in the legislature. ${ }^{16}$

The oldest parliamentary system of government is England, dating back to the beginning of the 18th century. The King of England cannot be contested (the King can do no wrong), and if there is a dispute between the king and the people, the minister is responsible for all the king's actions. This accountability is not only criminal responsibility but also political accountability, meaning that ministers in the cabinet are responsible for all government policies to parliament. Ministers who do not have parliamentary support must resign.

\section{Party System}

Each democracy applies a different party system. The party system is measured based on the number of political parties in a country. According to Maurice Duverger, the party system can be divided into three namely one-party systems (one-party system / singleparty system), two-party system (two-party system / dual party

15 Moh. Kusnardi dan Harmaily Ibrahim, op.cit. page. 172

16 Miriam Budiardjo, op.cit. page. 210 
system), and multi-party system (multi-party system / multi-party system). ${ }^{17}$

The term single party system is used for parties that truly are the only political parties in a country, as well as for political parties that have a dominant position among several other political parties. This single-party system can be caused because the state administration system wants a single party, or it can occur because of certain political constellations so that there is only one dominant political party continuously.

The dominant political party in a one-party system or a singleparty system in a country is called part instant, and the regime is called Partito crazy. These political parties dominate the state and "colonize" important areas of the state and society so that they tend to abuse power. This single-party system is one of the characteristics of an autocratic state. ${ }^{18}$

The two-party system or two-party system is a political system in a country that has two main parties (major parties) with the possibility of another political party, but not significant. There are only two political parties whose power may control parliament, or form a government. The formation of two main political parties related

17 Ni'matul Huda dan Imam Nasef, Structuring Democracy \& Elections in Indonesia after Reformation, Fajar Interpratama Mandiri, Jakarta, 2017, page, 36

18 Mochamad Ali Syafa'at, Dissolution of Political Parties Arrangements and Practice Dissolution of Political Parties in Republican Struggle, Raja Grafindo Persada, Jakarta, 2011, page, 59 to the system and social background of a country. ${ }^{19}$

In the dual party system, political parties are divided into the ruling party (because it won the general election) and the opposition party (because it lost the general election). ${ }^{20}$

A multi-party system is a political system wherein a country there is not a single political party that may be an absolute majority to be able to control the representative institutions or form a government without forming a coalition with other political parties.

The multi-party system has advantages, especially for countries that have heterogeneous societal structures. But on the other hand, the multiparty system has weaknesses in terms of the resulting government, which tends to be unstable because there are no dominant political parties, especially in countries with parliamentary government systems. The multi-party system is usually strengthened by a proportional representation election system that provides broad opportunities for the growth of small political parties. ${ }^{21}$

\section{The Ideal Combination of Government Systems and Party Systems for Government Stability and Effectiveness}

The government system adopted or practiced in Indonesia in its history has changed, along with the practice of Indonesian state

19 Ibid., page, 60

20 Miriam Budiardjo, $\mathrm{P} p$ cit, page, 168

21 Ibid., page, 62 
administration, starting from the parliamentary governmenat system, presidential quasi-government system, and presidential government system. At the beginning of independence, the 1945 Constitution did not explicitly mention the Indonesian government system, whether presidential or parliamentary. After Indonesian independence, Indonesian leaders agreed to form a parliamentary cabinet government. The Prime Minister who heads the first parliamentary cabinet is Syahrir. The parliamentary system of government in the history of the Indonesian state administration lasted until the issuance of the Presidential Decree on July 5, 1959, one of which contained the reenactment of the 1945 Constitution.

After 1959, the system of government adopted was the quasipresidential system. The 1945 Constitution, after being re-enacted by Presidential Decree July 5, 1959, until the end of the New Order government in 1998, never changed. Amendments to the Constitution were made by the MPR during the Reformation era. The MPR in making amendments to the 1945 Constitution was right, one agreement was to reinforce the presidential government system, not a mixed quasi-presidential system but to purify the presidential government system or the purification of the presidential government system.

Indonesia is a country with a presidential government system. This matter based on the founding father's agreement in the meeting of the Agency Investigator of the Independence Preparatory Business (BPUPK) on May 29-June 1 and July 10-17 $1945 .{ }^{22} \mathrm{~A}$ basic agreement to reinforce a presidential government system aims to strengthen a stable, effective, and democratic government system. To affirm the Indonesian presidential government system, the President and Vice President are one of the highest executive power institutions under the 1945 Constitution of the Republic of Indonesia. ${ }^{23}$ Since 2004, the President and Vice President have been directly elected by the people. With this direct election by the people, the President is not politically accountable to the MPR, but is directly responsible to the people who elect him. The President and / or Vice President can be held legally liable if the President and / or Vice President violates the law. To limit the power of the President which in the presidential system of government has a very strong position in accordance with the need to guarantee the stability of the government, a fixed term of the President is determined to be five years and only twice the same term. The President is both the head of state and head of government. Political power and

22 Ahmad Yani, Indonesian Government System: Theory and Approach Practice, Journal Lentera Hukum, Volume 5 Issue 2, July 2018, page 252 .

23 Jimly Asshiddiqie, The Indonesian Constitution and Constitutionalism, the General Secretariat and the Registrar's Office of the Constitutional Court Indonesian republic, Jakarta, 2006, page, 75-76 
responsibility rests with the President (concentration of power and responsibility upon the President). Ministers are appointed and dismissed by the President, so that the ministers are responsible to the President.

Changes to the provisions regarding the election of President and Vice President directly elected by the people are also based on the thought to manifest the sovereignty of the people. In addition, the election of the President and Vice President directly by the people, makes the President and Vice President elected have strong legitimacy. Especially in the provisions of Article 6A paragraph (2) of the 1945 Constitution of the Republic of Indonesia stipulating that to be appointed President and Vice President, they must obtain more than fifty percent of the votes in the general election with at least twenty percent of the votes in each province is spread over more than half of the provinces in Indonesia.

The President and Vice President who are directly elected by the people have strong legitimacy so that the elected President and Vice President cannot be imposed or dismissed in his term of office for political reasons. They can be dismissed during their term of office only if they violate the law based on the provisions contained in the 1945 Constitution of the Republic of Indonesia through a constitutional procedure, known as impeachment or impeachment. Impeachment of the President and/or Vice President is carried out through legal proceedings through the constitutional court in the Constitutional Court.

The presidential government system that is being implemented at the moment is still left with problems. The first problem that arises in relation to the implementation of a presidential government system in Indonesia is its combination with the party system. In many countries, a presidential government system is followed by a simple party system, although there are also countries where the government system is presidential but the party system is not simple (multiparty). In the United States for example, the system of government is presidential and there are only two political parties (Republicans and Democrats). This is considered more effective by his government, because with this model, there will be one political party in power, while other political parties will become the opposition, which will control the government. So ideally, a presidential government system is implemented in conjunction with a two-party system. While the Indonesian presidential government system is applied side by side with the multi-party system. The combination of a presidential government system with a multiparty system is considered to affect the stability and effectiveness of the government, because it tends to cause conflicts between the presidential institution and the parliamentary institution. Especially if the political party supporting the president is not a majority party in the parliament, then the president's policy will be difficult or require a 
long time to get support from the parliament. Likewise parliamentary control over the government tends to be excessive. Therefore, a multiparty presidential system requires a coalition of political parties. Without a coalition, it will be difficult to get a majority power in parliament, and this will have an impact on parliamentary support for the President's policies. Unfortunately, the political party coalition model in Indonesia is very pragmatic, fragile, and impermanent. The coalition of political parties is very fluid. Political parties form coalitions for only a brief political interest, especially in carrying the pairs of candidates for President and Vice President or carrying pairs of Regional Heads and Deputy Regional Heads. The coalition of political parties was carried out in connection with the regulation on the threshold for nominating the President and Vice President and also the nomination of the pairs of Regional Head and Deputy Regional Head. At the national level, at the nomination of President and Vice President, political parties may be at odds and not get along, but at the regional level they embrace each other, and vice versa. Coalition of political parties at the regional level is not always perpendicular to the coalition of political parties at the central level. Whereas ideally political parties will do coalitions if they have the same ideology or the same view. However, the current coalition of political parties is not related to ideological similarities, but only for the sake of political interests to fulfill the requirements for the nomination of the President and Vice President and the nominations of Regional Heads and Deputy Regional Heads.

The above situation will further complicate the support of parliament to the President. As a result, the President is very compromising, for example in forming a cabinet, the President will get intervention from his coalition political parties to put party cadres in the cabinet ranks. It will be more difficult for the President of the coalition of political parties is very fat, because there will be more cadres or members of coalition political parties that must be included in the Cabinet. If the interests of coalition political parties are not accommodated by the President, then political parties can withdraw their support, then leave the coalition, and even the threat of impeachment from the parliament can emerge. Unloading cabinet pairs is very likely to occur, as happened when the National Mandate Party (PAN) which was originally a political party supporting the President's coalition, then left the coalition of supporting political parties and supporters of President Joko Widodo who competed in the 2019 presidential and vice-presidential elections, then the minister from PAN, Asman Abner, the Minister for Administrative Reform and Bureaucratic Reform (MenpanRB) resigned and had to be replaced by the Commissioner-General who was then serving as Deputy Chief of Police Syafruddin. With the entry and exit of political parties in the 
coalition, the President will be preoccupied with the affairs of the political party coalition, so that government affairs can be ignored.

In addition to dismantling cabinet pairs, a combination of presidential government systems and multi-party systems can also influence decision making or policymaking by the President. This happens because in decision making or policymaking, the President will consider the interests of coalition political parties which of course have different interests. The fatter the coalition, the longer the decision making or policymaking. This has become ineffective and will also weaken the Indonesian presidential government system.

To overcome this problem, the thing to do is to change the party system from a multi-party to a simple multi-party, and if possible is with two parties. With a twoparty system, the government will be able to run stable and effective, because in elections one political party will be the winner and come to power, while the other political parties will act as the opposition. The winning political party will form its government without forming a coalition. The President in compiling the cabinet without having to think about the interests of other political parties, and can concentrate on the administration of government so that his government becomes stable and effective.

The second issue is in the case of the horizontal distribution of powers between the executive, legislative, and judiciary. Amendments to the 1945 Constitution gave the power to form laws to the DPR. In Informingws, the DPR is not alone, but must be with the President, and also involve the DPD for the formation of laws which are the authority of the DPD, namely relating to regional autonomy, central and regional relations, the formation and expansion and merging of regions, management of resources natural and other economic resources, as well as those related to central and regional financial balances. The formation of laws involving the executive will also weaken the presidential government system. To overcome this problem, in the future it will be enough for the DPR and DPD to act as legislative bodies without involving the President. The position of the DPR and DPD are equally strong in accordance with their representation function. The DPR represents the interests of the people, while the DPD represents the interests of the region.

\section{CONCLUSION}

The weakness of the Indonesian presidential government system is that it combines with a multi-party system. This will be able to disrupt the stability and effectiveness of government, because: $a$. there must be a coalition of political parties in government; b. with the coalition of political parties, the cabinet arrangement by the President must consider and accommodate the interests of the coalition political parties; c. decision-making or policymaking must also consider the interests of coalition political parties so that it will take longer; $d$. the coalition of political parties is very 
fluid and pragmatic so that there will be a change in the coalition, because there is a possibility that political parties that were outside the coalition then enter the government coalition, and vice versa; e. the exit and entry of political parties in the government coalition will certainly be very disturbing because political parties who have just joined the government will demand a ration of seats in the government, especially in the cabinet, so that there will often be dismantling pairs of cabinet.

To reinforce the presidential system of government, ideally, it should be combined with a two-party system or a simple party system. Therefore, what needs to be done in Indonesia is to change the party system from a multi-party system to a simple multi-party system, or if possible with a two-party system. Efforts to simplify political parties have been carried out by applying the parliamentary threshold, but it has not been effective. For this reason, it is necessary to increase or increase the percentage of parliamentary threshold, or explicitly limit the number of political parties.

Horizontal separation of powers between executive, legislative, and judicial powers has not been carried out explicitly. This can be seen in the formation of legislation still involving the Parliament and the President, and for laws with certain material content involving the DPD. In this regard, to reinforce the presidential government system, the formation of the law will be carried out without involving the President, but only the legislative body, namely the DPR and DPD.

Books :

\section{BIBILIOGRAPHY}

Jimly Asshiddiqie, 2006, Constitutional Law and Pillars of Democracy, Flakes of Legal Thinking, Media, and Human Rights, Secretariat General and Registrar of the Constitutional Court Indonesian Republic, Jakarta. 2006, The Indonesian Constitution and Constitutionalism, the General Secretariat and the Registrar's Office of the Constitutional Court Indonesian Republic, Jakarta.

Laica Marzuki, 2006, Take a walk in the Law Domain, Book I, Secretariat General and Registrar of the Constitutional Court Indonesian Republic, Jakarta.

Miriam Budiardjo, Maret 1985, Fundamentals of Political Science, Print IX, Gramedia, Jakarta,

Mochamad Ali Syafa'at, 2011, Dissolution of Political Parties Arrangements and Practice Dissolution of Political Parties in Republican Struggle, Raja Grafindo Persada, Jakarta,

Moh. Kusnardi dan Harmaily Ibrahim, 1983, Indonesian Constitutional Law, Print V,Center for Constitutional Law Studies, Faculty of Law of Indonesian University, Sinar Bakti, Jakarta, 
Mukti Fajar dan Yulianto Achmad, 2010, The dualism of Normative \& Empirical Law Research, Print I, Pustaka Pelajar, Yogyakarta.

Manuscript Comprehensive Amendment to the 1945 Constitution of The Republic of Indonesia, Background, Process, and Results of Discussion 1999-2002, Book I, Secretariat General and Registrar of the Constitutional Court, 2010, Jakarta,

Ni'matul Huda dan Imam Nasef, 2017, Structuring Democracy \& Elections in Indonesia after Reformation, Fajar Interpratama Mandiri, Jakarta.

Peter Mahmud Marzuki, 2005, La nstitutions that have the right to adjust the Constitution as the highest law with the demands of the times is the country's highest institution, the MPR. Research, Prenada Media, Jakarta.

\section{Jurnal :}

Cora Elly Noviati, Democracy and Government System, Journal of Constitution Volume 10 Number 2, June 2013.

Ahmad Yani, Indonesian Government System: Theory Approach and Constitutional Practice of 1945 Law, Journal Legislasi Indonesia, Volume 15, Number 2, Juli 2018

Muliadi Anangkota, Theoretically the system government experienced progression from classical to modern, Journal Cosmogov, Volume 3, Number 2

Ahmad Yani, Indonesian Government System: Theory and Approach Practice, Journal Lentera Hukum, Volume 5 Issue 2, July 2018

Sofian Effendi, The government system is a national Identity, Journal Ketahanan Nasional, Volume 10 Number 2, 2005 